Mexico as a new dawn following the chaos of the 2009 Copenhagen meeting, then the Durban negotiations must now make a break from the past. Already, familiar battle lines have been drawn, and flags flown on stand-offs such as the future of the Kyoto Protocol, the global agreement that sets targets for emissions reductions. For years, environmental campaigners at the United Nations climate summits would stalk the corridors and the press room and rapidly correct anyone who claimed that the Kyoto Protocol expired in 2012. It was only the first phase of the agreement that would end, they insisted, finding hope in the implicit promise that other phases would follow. No longer - one of the hottest debates at Durban will probably boil down to whether the protocol will continue in its present form at all.

In a Comment on page 291, Elliot Diringer of the Center for Climate and Energy Solutions in Arlington, Virginia (formerly the Pew Center on Global Climate Change) makes the case that it should not. His argument - that the protocol has become an obstacle to international progress and should be consigned to history - will be popular along the interstate in Washington DC.

It is certainly pragmatic: the odds of China and the United States taking on binding emissions targets, for now, he says, are "nil", which will keep away Japan, Canada and Russia, and so fatally punch a hole below the waterline in the common-but-differentiated approach taken under Kyoto. "A binding-or-nothing mentality," has underpinned the climate talks for too long, Diringer says. "And the result often has been nothing."

Advocates of the multibillion-dollar carbon market established across Europe as a direct result of the Kyoto agreement would no doubt disagree with that assessment — as would the US airlines fighting tooth and nail to avoid being dragged into the emissions-trading scheme from next year. Many developing countries, too, would defend Kyoto, if only because it has made no serious demands of them and they enjoy seeing their wealthier rivals squirm.

But the world has changed since the formative years of the Kyoto Protocol in the 1990s, when it neatly allocated its countries into two camps — rich and poor - divided by a common purpose.

As Diringer points out, some $58 \%$ of global emissions now come from developing countries, and although a handful of rich

"Dogmatic adherence to the protocol is now a political liability." relatively small dent in emissions, with the prospect of significantly bigger dents to come. Without the world's two largest polluters the United States and China - on board that now seems impossible. Another goal was to establish and test an international architecture for reducing greenhouse-gas emissions and eventually scale it up. Without the world's two largest polluters, that now seems pointless.

To ditch the agreement - the only global regulation on greenhouse gases - may seem a dramatic move, and in a way it is, particularly for those who have long believed in it. But the implications need not be severe. Europe can, and should, maintain its carbon market and its commitments, just as the offset mechanism developed under the protocol can continue. The real benefits of Kyoto - practical experience and institutional structures - can endure without it.

Like it or not, a dogmatic adherence to the protocol is now a political liability that threatens cooperative action (however limited) over climate change - such as deals to secure finance for the most affected countries to help them with strategies for adaptation. There is no need to kill it. The treaty is already weakened and will prove hard to revive. The Durban meeting should be where the Kyoto Protocol, as we know it, goes to die.

\section{Ex factor}

\section{Demise of snails in a New Zealand freezer is a sign of the times.}

\section{$\mathrm{T}$} he world just got a little smaller. If you go down to the woods today in search of a western black rhinoceros (Diceros bicornis longipes) you'll be out of luck. Those at the International Union for Conservation of Nature, whose task it is to maintain the Red List of endangered species, have been looking high and low for western black rhinos for some time, but in vain. Last week, they called off the search and declared it extinct. Most of us will never have knowingly met a western black rhino. One feels a keen sense of its passing nonetheless - a sensation to which we are becoming accustomed. Rhinophiles will also, no doubt, be aware that the northern white rhino (Ceratotherium simum cottoni), a cousin of the late western black rhino, is on the brink of extinction, and that the last Javan rhino (Rhinoceros sondaicus) outside Java is also believed to have disappeared.

Conservation news is not all bad. The efforts of conservationists to rescue populations from the wild, breed them in captivity and reintroduce them, sometimes pay off. Przewalski's horse (Equus ferus przewalskii) was listed as extinct in the wild in 1996, but was brought back after a captive breeding programme, and the wild population is now believed to exceed 300. The Arabian oryx (Oryx leucoryx) is also on the up, albeit gingerly. Thanks to captive breeding and reintroductions - intentional or otherwise - the howls of wolves are heard once more where they had been absent for centuries, and wild boar (Sus scrofa) are believed to infest parts of Britain with a vigour that would shame an urban cockroach.

Less well publicized, perhaps, are the woes of endangered creatures too small, obscure or superficially revolting to attract headlines. Conservationists have long understood that the public categorizes creatures into two kinds - Cute and Yucky. The land snail Powelliphanta augusta tends, arguably, to fall into the latter class. Mature individuals grow to the size of a fist. A rapacious carnivore, it survives by sucking worms out of the ground. Clearly, it is a species that only its mother could truly love. It was discovered in 1996 in a remote mountain ridge on the South Island of New Zealand, its sole known place of residence. Unluckily for the marauding mollusc, its entire range was due to be demolished to make way for an opencast coalmine. About 4,000 snails were caught and released in another part of the area, with 1,600 being placed at their preferred temperature of $10^{\circ} \mathrm{C}$ in chiller units in a government conservation-department facility. Unfortunately, a fault in a sensor plunged the temperature in one of the units to zero, and 800 of the snails - a sizeable fraction of the entire species - froze to death. The fault was not noticed immediately because it happened over a public holiday.

The incident highlights an important fact long known in conservation biology, that as species shrink in number, they become ever more vulnerable to sudden mishaps. To suffer because of, say, an avalanche or a brushfire is unfortunate - after all, species have evolved and become extinct innumerable times throughout Earth's history without the interference of Homo sapiens. So it is sad that P. augusta has come closer to extinction as a result of people's efforts to prevent such an eventuality. But one might, if one were so minded, also look askance at the decision to plonk an opencast mine on the snail's habitat. How

$\rightarrow$ NATURE.COM To comment online, click on Editorials at: go.nature.com/xhunqv different it might have been had the snails been able to disguise themselves as fluffy polar bear cubs or baby pandas. Conservationists can only do so much. When backed with political will, they can do much more. 